\title{
A new species of the genus Mycetophagus Fabricius, 1792 (Coleoptera: Mycetophagidae) from China
}

\section{Новый вид рода Mycetophagus Fabricius, 1792 (Coleoptera: Mycetophagidae) из Китая}

\section{J. Háva \\ И. Гава}

Daugavpils University, Institute of Life Sciences and Technology, Department of Biosystematics, Vienîbas Str. 13, Daugavpils, LV-5401, Latvia; Private Entomological Laboratory and Collection, Rýznerova 37, CZ-252 62 Únětice u Prahy, Praha-západ, Czech Republic. E-mail: jh.dermestidae@volny.cz.

Даугавпилсский университет, Институт естественных наук и технологий, отдел биосистематики, Даугавпилс, Латвия; Частная энтомологическая лаборатория и коллекция, Прага, Чехия.

Key words: taxonomy, description, new species, Coleoptera, Mycetophagidae, Mycetophagus, China.

Ключевые слова: таксономия, описание, новый вид, Coleoptera, Mycetophagidae, Mycetophagus, Китай.

Abstract. A new species, Mycetophagus (Ilendus) yunnanus sp.n. is described and illustrated from China (Yunnan), and compared with two eastern Palaearctic congeners.

Peзюме. В статье описывается новый вид Mycetophagus (Ilendus) yunnanus sp.n. из Юньнаня (Китай). Новый вид сравнивается с двумя близкими восточнопалеарктическими видами.

\section{Introduction}

The genus Mycetophagus Fabricius, 1792 is divided into 11 subgenera and contains 36 species from the Palaearctic Region [Nikitsky, 2008; Saitô, 2013]. Only two species have been known from China so far [Nikitsky, 2008]. During the determination of mycetophagid collection deposited at the Naturkundemuseum, Erfurt, Germany, I found a new Mycetophagus Fabricius, 1792 species from China as described below.

\section{Material and Methods}

The size of the beetles or of their body parts can be useful in species recognition and thus, the following measurements were made: (1) total length (TL) — linear distance from anterior margin of head to apex of elytra;(2) elytral width $(\mathrm{EW})$ - maximum linear transverse distance.

The material is deposited in the following collections: NME - Naturkundemuseum, Erfurt, Germany; JHAC — Jiří Háva, Private Entomological Laboratory \& Collection, Únětice u Prahy, Prague-West, Czech Republic.

Specimens of the presently described species are provided with red, printed labels with texts as follows: «HOLOTYPE (or PARATYPE respectively) Mycetophagus (Ilendus) yunnanus sp. nov. Jiří Háva det. 2019».

\section{Results}

Mycetophagus (Ilendus) yunnanus Háva, sp.n. Figs 1-5.

Type material. Holotype $\left(O^{T}\right)$ : CHINA: Yunnan/Honghe, Dajiashan, $2060 \mathrm{~m}, \mathrm{EKL} 5,22^{\circ} 54^{\prime} 46.5^{\prime \prime} \mathrm{N}, 103^{\circ} 41^{\prime} 51.5^{\prime \prime} \mathrm{E}$, 30.v.2018, L.Z. Meng leg. (NME). Paratypes: $\left(1 \sigma^{7}\right)$ : same data as holotype, (NMED) [specimen without four legs and abdomen]; (2 +o): same data but 21.v.2018 (DJS55), (NME, JHAC).

Description. Male. Body measurements TL $6.45 \mathrm{~mm}$, EW $2.62 \mathrm{~mm}$; elongate-oval, subparallel-sided; weakly convex dorsally, weakly glossy; mostly brown, covered with brownish and yellow recumbent setation; mouth parts, legs brown; elytra brown with yellowish-brown patches.

Head with dense and coarse punctures; ocular distance about 2.7 times wider than diameter of eyes; covered by yellowish, erect setation; labrum brown; eyes prominent laterally in dorsal view, coarsely faceted and slightly emarginate near antennal insertions; antennae with 11 antennomeres, antennomeres I-VI brown, VII-XI black, antennal club with five antennomeres (Fig. 3); palpi dark brown, apical maxillary palpomere cylindrical.

Pronotum convex dorsally, rugose, with large and dense punctures; widest at middle, gradually narrowed anteriad and posteriad; anterior margin slightly arcuate; lateral sides distinctly margined, roundly arcuate; basal margin sinuate, with short and circular grooves at subbasal parts.

Scutellum triangular, with short recumbent brown setation.

Elytra with yellow and brown recumbent setation, elongate, subparallel-sided, narrowed from apical $1 / 4$ part to apex; dark brown with many small, large and geometric yellowish-brown patches (Figs 1-2), which are variable among individuals; punctate-striate, strial punctures very deep, large and regular; interstices flat, narrower than striae.

Meta-meso ventrite dark brown, with yellow recumbent setation.

Abdominal visible ventrites brown, with yellow recumbent setation.

Male genitalia as in figs $4-5$. 

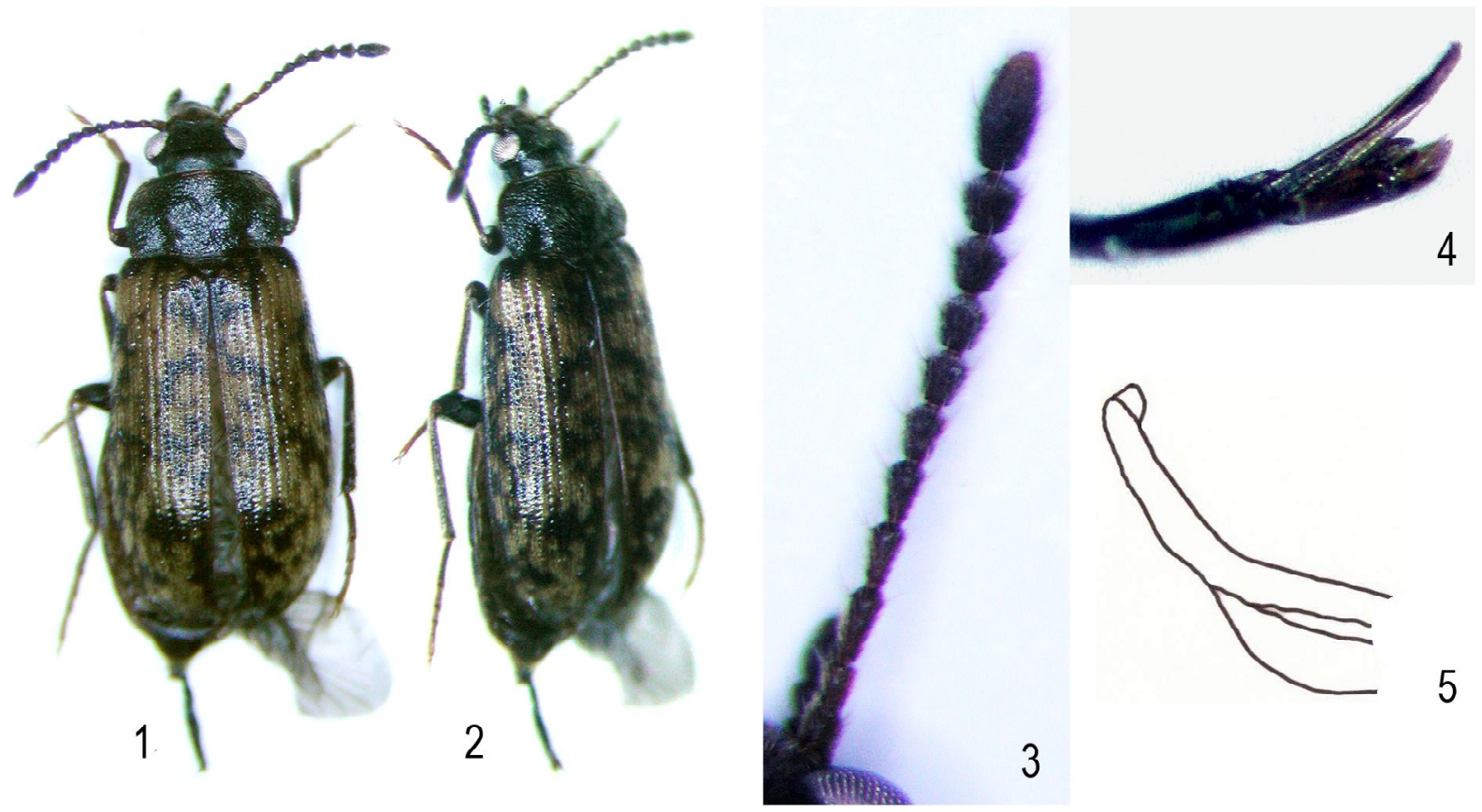

Figs 1-5. Mycetophagus (Ilendus) yunnanus sp.n.: 1 - habitus, dorsal aspect; 2 - habitus, lateral aspect; 3 - antennae; 4 male genitalia, dorso-lateral aspect; 5 - male genitalia, tip of median lobe, lateral aspect.

Pис. 1-5. Mycetophagus (Ilendus) yunnanus sp.n.: 1 - внешний виА, сверху; 2 - внешний виА, сбоку; 3 - усик; 4 гениталии самџа, дорсо-латерально; 5 - гениталии самџа, вершина серединной доли, сбоку.

Female. Externally similar to male.

Variability. Body measurements TL $6.0-6.2 \mathrm{~mm}$, EW 2.4-2.7 mm.

Differential diagnosis. The new species belongs to the subgenus Ilendus Casey, 1900 according characters menitioned by Nikitski [1993] and differs from the similar eastern Palaearctic species M. irroratus Reitter, 1879 and M. lederi Reitter, 1897 by the following characters:

- antennomeres VII-XI brown or brown-black; head and pronotum brownish-black; elytra as in Fig. 6 a-d M. irroratus Reitter, 1879

- antennomeres VII-XI black; head and pronotum black; elytra as in Figs 1-2 . M. yunnanus sp.n.

- antennomeres VIII-XI light brown or reddish-brown; elytra as in Fig. 6 e ........................ lederi Reitter, 1897

Etymology. Toponymic, named according to the province Yunnan of China,

\section{Acknowledgements}

I am very obliged to Matthias Hartmann (NME) for loaning me the interesting material, to the two reviewers Yun Hsiao (Australia) and Jens Esser (Germany) for comments and to Miloslav Rakovič (Czech Republic) for linguistic revision of the manuscript.

\section{References}

Nikitsky N.B. 1992. Opredelitel nasekomykh Dalnego Vostoka SSSR. Tom III. Zhestkokrylye, Zhuki. Chast 2 [Keys to the identification of insects of the Soviet Far East. 3 Coleoptera,
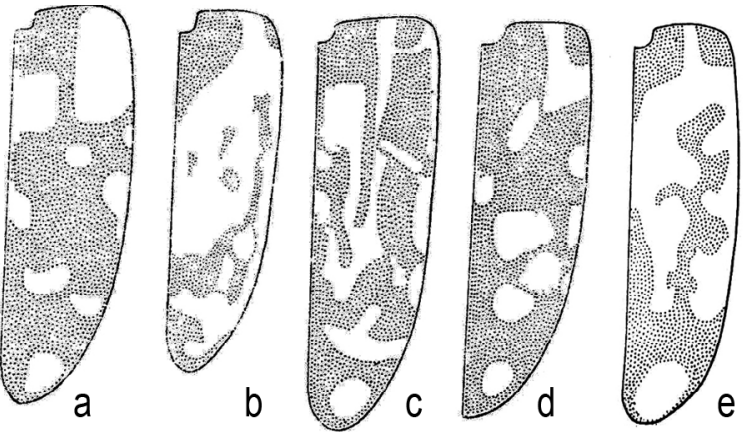

Figs 6. Elytra: a-d - M. irroratus Reitter, 1879; e M. lederi Reitter, 1897 (according to Nikitsky [1992]).

Рис. 6. Надкрылья: a-d - M. irroratus Reitter, 1879; е M. Lederi Reitter, 1897 (из Nikitsky [1992]).

or beetles. Part 2]. Semeistvo Mycetophagidae. P.406-423. Semeistvo Tetratomidae // Ler P.A. (Ed.). St.-Petersburg: Nauka. P.426-435. [In Russian].

Nikitsky N.B. 1993. Zhuki-griboedy (Coleoptera, Mycetophagidae) Fauny Rossii I Sopredelnych Stran. M.: MGU. 183 p. [In Russian].

Nikitsky N.B. 2008. Family Mycetophagidae Leach, 1815 // Löbl I., Semetana A. (Eds): Catalogue of Palaearctic Coleoptera. Vol.5. Tenebrionoidea. Stenstrup: Apollo Books, $670 \mathrm{p}$.

Saitô M. 2013. Two new species of the genus Mycetophagus (Coleoptera, Mycetophagidae) from the Yaeyama Islands, Southwest Japan // Elytra. Vol.3. No.1. P.97-100. 